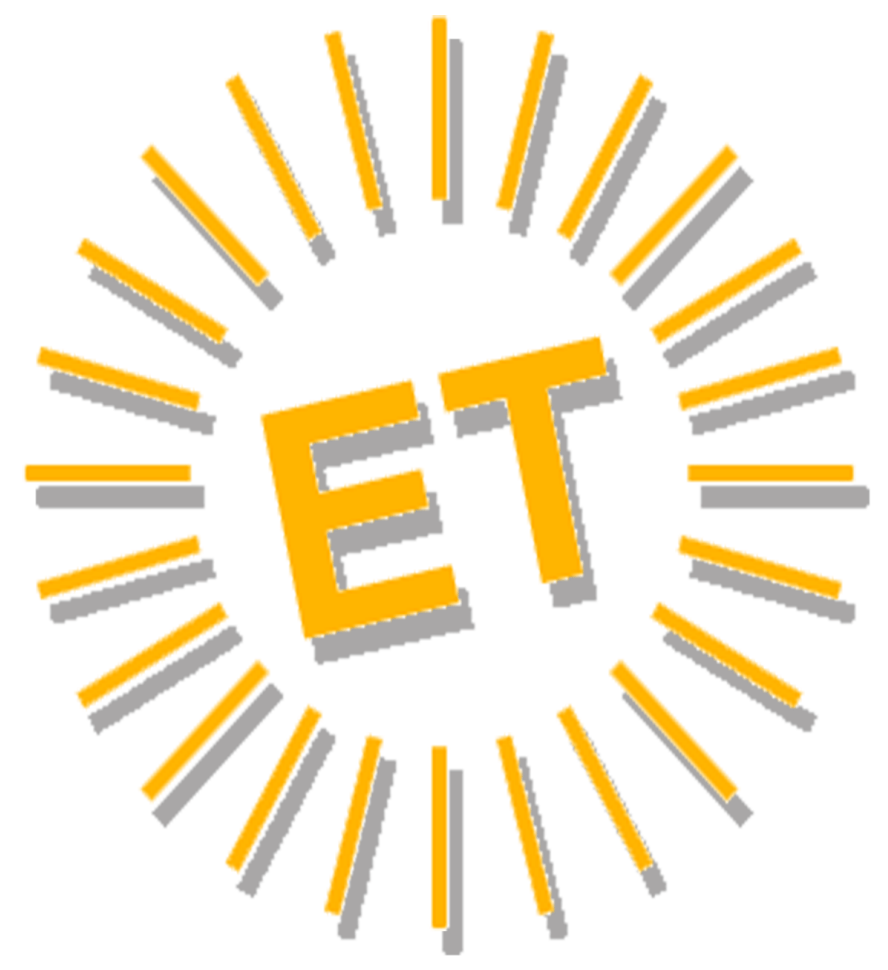




\section{Editorial Team}

\section{Editor in Chief}

Alfonso Vargas-Sánchez, University of Huelva, Spain

\section{Associate Editor}

Mirko Perano, Reald University College, Albania

\section{Books Review Editor}

Brendan Paddison, York St. John University, United Kingdom

\section{Secretariat}

Elena García de Soto, University of Huelva, Spain

Cinta Borrero-Domínguez, University of Seville, Spain

\section{Style reviewer and text editor}

Anestis Fotiadis, Zayed University, United Arab Emirates

\section{Editorial Board}

José Manuel Alcaraz, Murdoch University, Australia Mario Castellanos-Verdugo, University of Seville, Spain José Antonio Fraiz-Brea, University of Vigo, Spain José Manuel Hernández-Mogollón, University of Extremadura, Spain

Tzung-Chen Huan, National Chiayi University, Taiwan, Province of China

Shaul Krakover, Ben Gurion University, Israel Jean Pierre Levy-Mangin, University of Quebec, Canada Tomás López-Guzmán, University of Córdoba, Spain Yasuo Ohe, Chiba University, Japón

María de los Ángeles Plaza-Mejía, University of Huelva, Spain Nuria Porras-Bueno, University of Huelva, Spain João Albino Silva, Algarve University, Portugal

\section{Advisory Board (Spanish Members)}

Juan Manuel Berbel-Pineda, Pablo de Olavide University, Spain César Camisón-Zornoza, Uniersity of Valencia, Spain Enrique Claver-Cortés, University of Alicante, Spain María Teresa Fernández-Alles, University of Cádiz, Spain José Luis Galán-González, University of Seville, Spain Félix Grande-Torraleja, University of Jaén, Spain

Antonio Leal-Millán, University of Seville, Spain Inmaculada Martín-Rojo, University of Málaga, Spain Antonio Manuel Martínez-López, University of Huelva, Spain Francisco José Martínez-López, University of Huelva, Spain Pablo A. Muñoz-Gallego, University of Salamanca, Spain
Francisco Riquel-Ligero, University of Huelva, Spain José Miguel Rodríguez-Antón, Autonomous University of Madrid, Spain

Sandra Sanchez-Cañizares, University of Cordoba, Spain Josep Francesc Valls-Giménez, ESADE, Spain

\section{Advisory Board (Other European Members)}

Tindara Abbate, University of Messina, Italy Paulo Aguas, University of Algarve, Portugal Carlos Costa, Aveiro University, Portugal Dianne Dredge, Aalborg University, Denmark Salvatore Esposito de Falco, University of Rome "La Sapienza", Italy

Sheila Flanagan, Dublín Institute of Technology, Ireland Tania Gorcheva, Tsenov Academy of Economics, Bulgaria Tadeja Jere Jakulin, University of Primorska, Slovenia Metin Kozak, Mugla University, Turkey Álvaro Matias, Lusiada University, Portugal Alfonso Morvillo, National Research Council, Italy Alexandru Nedelea, Stefan cel Mare University of Suceava, Romania Claudio Nigro, University of Foggia, Italy Angelo Presenza, University "G. D'Annunzio" of Chieti-Pescara, Italy

Kanes Rajah, Royal Agricultural University, United Kingdom

\section{Advisory Board (Members from the rest of the world)}

John Allee, American University of Sharjah, United Arab Emirates

Nestor Pedro Braidot, National University of La Plata, Argentina

Roberto Elias Canese, Columbia University, Rector, Paraguay

Luca Casali, Queensland University of Technology, Australia Nimit Chowdhary, Indian Institute of Tourism and Travel Management, India

Steven Chung-chi Wu, National Pingtung University of Science and Technology, Taiwán

Dianne Dredge, Southern Cross University, Australia Daniel Fesenmaier, Temple University, United States

Babu George, Alaska Pacific University, United States Dogan Gursoy, Washington State University, United States Jafar Jafari, University of Wisconsin-Stout, United States Sanggun Lee, Pai Chai University, Korea Republic of Albert Yeh Shangpao, I-SHOU University, Taiwán Pauline Sheldon, University of Hawaii, United States Germán A. Sierra-Anaya, University of Cartagena de Indias, Rector, Colombia Xiaohua Yang, University of San Francisco, United States 


\title{
THE USABILITY OF I-SUYYAH: A MOBILE TOURISM APPLICATION FOR ARAB TOURISTS IN MALAYSIA
}

\author{
Wan Ab Aziz Wan Daud \\ Universiti Malaysia Kelantan (Malaysia) \\ abaziz.wd@umk.edu.my \\ Mohammad Taufiq Abdul Ghani \\ Universiti Pendidikan Sultan Idris (Malaysia) \\ taufiq@fbk.upsi.edu.my
}

Ahmad Zaki Amiruddin

Universiti Malaysia Kelantan (Malaysia)

ahmadzaki@umk.edu.my

Kamarulzaman Abdul Ghani

Universiti Malaysia Kelantan (Malaysia)

kamarulzaman@umk.edu.my

Ahmad Abdul Rahman

Universiti Malaysia Kelantan (Malaysia)

ahmad.ar@umk.edu.my 


\section{ABSTRACT}

Globalisation and the rapid growth of technologies call for ease and automation in different aspects, including in tourism. Tourism is an important sector in Malaysia as it generates income for the country. In recent years, Malaysia has seen a surge in the arrival of high-spending Arab tourists. This reflects the need to provide a tool, specifically a tourism mobile application in the Arabic language, that could help ease their journey in Malaysia. Thus, this study aims to determine the usability of the i-Suyyah mobile application for Arab tourists in Malaysia. The data obtained were analysed using the Fuzzy Delphi method, and twelve experts were selected to analyse the fuzziness consensus. It was found that the i-Suyyah mobile application recorded a high percentage of expert consensus, specifically on its usability. All usability items have reached unity with the threshold value of $d 0.2$, and the percentage of consensus among the expert group is more than $83 \%$.

\section{KEYWORDS}

Tourism; Destination; Arab; Fuzzy Delphi; Usability

ECONLIT KEYS

O31; O33; Z13; Z32

\section{INTRODUCTION}

People travel for different purposes, including for pleasure, business or education. In general, tourism involves travelling to and staying in places outside of their immediate environment for a period of not exceeding one year for leisure and not less than 24 hours for business or other purposes. Tourism can be domestic, where travellers can travel within their traveller's own country or international tourism, where travellers travel to other countries. International tourism is a great way for a country to highlight its unique culture and lifestyle, food and traditions and natural attractions to outsiders. The tourism industry plays a crucial role in the economic development in Malaysia since independence. Realising its importance, the government has established the Ministry of Tourism, Arts, and Cultures (MoTAC). Previously, the tourism industry was supervised by the Tourism Development Corporation of Malaysia (TDC) which was established on 10 August 1972 as an agency under the former Ministry of Trade and Industry. Subsequently, after the establishment of MoTAC on 20 May 1987, TDC was rebranded into Malaysia Tourism Promotion Board (MTPB) as part of the Malaysia Tourism Promotion Board Act 1992. MTPB focuses on promoting local attractions in Malaysia to domestic and international travellers. At present, MTPB is officially known as Tourism Malaysia.

The tourism industry is the third-highest contributor to Malaysia's Gross Domestic Product (GDP) after manufacturing and commodities. In 2018, tourism contributed 
approximately $5.9 \%$ of the GDP or RM 84.1 billion to Malaysia's annual revenue. This revenue is $2.4 \%$ or RM 8.2 billion higher than the revenue in 2017 (Bernama, 2018). Furthermore, the amount of spending by international tourists in 2018 is RM25.8 million, which is a slight decrease from RM25.9 million recorded in 2017. On the other hand, the spending per capita of international tourists increased by $2.9 \%$ to RM 3257 in 2018 from RM3266 in 2017. The highest expense comes from shopping (33.4\%), followed by accommodation (25.7\%) and food and beverages (13.4\%) (Bernama, 2018).

Due to its significance to the country's economy, the government has devised many initiatives to boost tourism in Malaysia and to make Malaysia one of the top tourist destinations in the global market. Just recently, the Malaysian government has launched the "Visit Truly Asia Malaysia 2020" campaign to reach ambitious targets of 30 million visitors and 100 billion Malaysian Ringgit in tourism receipts for 2020 .

The discussion above indicates that tourism is one of the main economic activity in Malaysia and highly contribute to the country's development. Subsequently, the revenue generated from tourism has created a boost in the economy. It provides more funds to build more infrastructures, maintain and improve facilities for public use and improve services in various sectors, including transportation, securities and health.

\section{BACKGROUND}

In recent years, Southeast Asian countries, including Malaysia, has become a tourism hotspot for travellers from the Middle East or Arabic countries (Tourism Malaysia, 2019). In 2017, 27000 Arab tourists visited Malaysia, and the number increased to 33000 in 2018 with total spending of RM 3.8 billion. Arab tourists are one of the highest spenders; tourists from Saudi Arabia are the highest spender, followed by other Gulf countries, specifically United Arab Emirates, Oman, Iran and Kuwait. The Malaysian government, through the Ministry of Tourism, has collaborated with several non-government agencies to promote Malaysia as the main tourist destination for Middle Eastern tourists. One of these initiatives is through media coverage and advertising, for instance, promoting tourism packages through radio ads in Dubai. Tourism Malaysia has also announced a collaboration with Air Arabia, the largest lowcost carrier in the Middle East and North Africa, to offer direct flights from Sharjah to Kuala Lumpur (Bernama, 2019). 
The most popular niche of tourism for Arab tourists include entertainment, adventure, and shopping (Ariffin \& Hasim, 2009; Michael et al., 2011). Leisure tourism is the most common among Arab tourists, where the main purpose of the holiday is entertainment and enjoyment (Firyaan, 2011). Studies also found that Arab tourists prefer destinations with different kinds of entertainment such as water sports, adventure resorts or the wilderness where they can have fun with their family. In this light, Arab travellers usually travel with their family members and prefer to rent private cars rather than use public transport. Furthermore, they prefer to stay at hotels with larger or interconnected rooms or suites and serviced apartments (Mick, 2007). As most Arab tourists spend their holiday shopping (Alsheikh, 2006), Arab tourists, in general, are considered as high spenders (Alganam, 2011). Hence, the Arab tourist market is deemed as a coveted market.

The robust development of the tourism sector in Malaysia calls for tourism services and facilities to be equilibrated with the evolution of technology. Over the past few years, mobile and smartphone technology has become a part of modern life. The use of smartphones has evolved from being a communication device into a platform to disseminate information and for education, business, and entertainment. On the other hand, while the number of Arab tourist arrivals to Malaysia keeps increasing, there is a lack of mobile tourism application tailored for Arab tourists to assist their travels in Malaysia. It could be observed that the tourism applications available in the marketplace provide general information in English as the main language. Thus, a specific app for Arab tourists could be designed to fulfil the demand for Arabic language tourism information for Arab tourists in Malaysia.

Based on this importance, this paper aims to examine the usability of the "i-Suyyah" mobile application for Arab tourists in Malaysia through expert consensus. The iSuyyah mobile application has several functionalities, including providing tourism information, promoting tourist attractions across Malaysia, present interactive maps to locate tourist attractions and provide recommendations of accommodation according to the tourists' preference. In this regard, the Arab language is used fully throughout the app. This reduces the language barrier and making it easier for Arab tourists to find information about Malaysia. 


\section{LITERATURE REVIEW}

When more consumers and vendors started to use ICTs for purchasing decisions and marketing campaigns, researchers became interested in implementing innovations in the tourism industry, such as smartphone and wireless technology (Liang \& Sun, 2014; Liu \& Zhang, 2014; Zhong et al., 2013). According to Liang \& Sun (2014), the majority of scholars (47.8\%) tend to explore the industrial contributions and market roles of mobile technology in the tourism sector, followed by the relationship between mobile technology and consumer behaviour and customers' motivation to use mobile technology during travel (30.5\%). Scholars in hospitality and tourism have paid the slightest attention to technological advancement in the sense of m-tourism (21.7 $\%)$.

The investigation of the status of $\mathrm{m}$-tourism implementation, such as investigating the research trends of mobile methodologies, such as near-field communication (NFC) (Hannam et al., 2014; Pesonen \& Horster, 2012), is a common topic in this cluster, as is summarising digital eras and past ICT adoption in the tourism industry (Buhalis \& Law, 2008; Thakran \& Verma, 2013; Zhong et al., 2013). The studies listed above primarily contribute general implications and understandings for both academics and service providers dealing with mobile technology's emergence and growth in this sector. These consequences and understandings are deemed critical, especially in light of the recent increase in both mobile data and personal mobile device use, as well as the widespread adoption of wireless local area network (WLAN) solutions, which has aided in the growth of m-tourism (D'Ambra \& Mistilis, 2010).

Previous research studies have shown that the aforementioned technical breakthrough can affect market functions in this field (Kennedy-Eden \& Gretzel, 2012; Marentakis \& Emiris, 2010; Mistilis et al., 2014). Several studies have studied the marketing effects of mobile technology in the tourism industry to recommend various ways to use mobile technology as a marketing tool. For example, the commercial practice of mobile advergames and explored the strong and weak points of this new mobile technology as a marketing method. Location-sensitive auction technologies in the tourism industry, according to Marentakis and Emiris (2010), will support auctioneers, mobile communications operators, and location-based service (LBS) providers by breaking down internet barriers and lowering connectivity costs; Pedrana 
(2014) examined the market potential of LBS and their impact on travel destinations. Latorre-Martinez et al. (2014) investigated the use of image-focused social media (primarily Flickr and Instagram) as marketing platforms for tourism consumption. Previous research has also explored mobile devices or utilities' marketing effects such as mobile hotel reservations, social-local-mobile (SoLoMo) marketing, and NFC (Egger, 2013; Mistilis et al., 2014; Wang \& Wang, 2010).

Continuous progress advances smartphone infrastructure, applications, and network infrastructure to offer new functions to travellers and service providers alike. Many mobile devices and apps have a significant impact on different facets of the tourism industry in recent decades and have been critical for further technological advancement. Burgess et al. (2012) contribute to evaluating m-tourism applications by providing a mobile internet content model, connectivity, delivery, and transaction (ICDT) flow. Stienmetz et al. (2013) investigate the factors affecting the overall usability of mobile destination management organisation (DMO) websites in website assessment, one of the core fields of technology science. Several surveys also highlight the industry's embrace of third-generation (3G) services (Hultkrantz, 2002), mobile travel recommendation systems (Beritelli \& Schuppisser, 2006), positioning data (Ahas et al., 2008), and smartphone augmented reality (AR) software (Yovcheva et al., 2012).

The majority of studies in this field seek to add to the discussion about the advancement and invention of m-tourism technologies, such as electronic tourist guides and interactive geospatial information systems (GIS) (Kenteris et al., 2009; Reilly et al., 2006; Said et al., 2009). Of all mobile-related services, technologies, and structures, recommender systems are receiving the most research focus. Several novel innovation recommendation systems are presented, which combine an original engine with a mobile 3D GIS architecture and enable the implementation of a locationaware front-end in the user's mobile device (Batet et al., 2012; Noguera et al., 2012). Related research has led to the advancement of recommender systems by broadening their concept by collaborative filtering approaches and using a ground-breaking evaluation approach to explore the interaction between contextual variables and item scores (Baltrunas et al., 2012; Gavalas \& Kenteris, 2011). LBS innovation is also addressed, and its design is enhanced by taking into account both live television and 
online shopping (Yim, 2015). Tatsiopoulos and Boutsinas (2010) propose an advanced mobile technology to service providers in the tourism sector. This technology allows visitors to share their views and communicate their information transparently with others to present and develop innovative mobile technology. Martin et al. (2012) provide a novel framework for deploying context-aware mobile services. Gil et al. (2010) concentrate on creating a multimedia tourism infrastructure topology for mobile devices with broadband, multicast, and broadcast connectivity capabilities.

The topic above helped to provide the foundation of how the mobile app phenomenon initially came into existence. It also shows how important it is in today's economy and how smartphones modify new travel resources. The app offers a range of features, such as review, experience sharing, images and messages. Thus, this research seeks to further improve the purpose of travel application through an Arabic tourism app, i-Suyyah, a user-friendly travel platform for Arab tourists in Malaysia.

\section{OVERVIEW OF THE I-SUYYAH APP}

In this study, a mobile application named i-Suyyah tourism app was designed for Arab tourists. The i-Suyyah app was developed using the Flatter platform and could be run using the Android operating system. The app has several main features, as described below.

\section{Main Menu}

The main menu is an important feature of an app as it could guide the users to navigate the app. The main menu for the i-Suyyah app lists down all 14 states in Malaysia and the tourist hotspots that appeal to Arab tourists in Malaysia. The users can choose the state they are interested in visiting, and they can obtain information about hotspots for Arab tourists. The app also has a "favourite" button so that they can bookmark their favourite destination. The figure below illustrates the main menu of the app. 


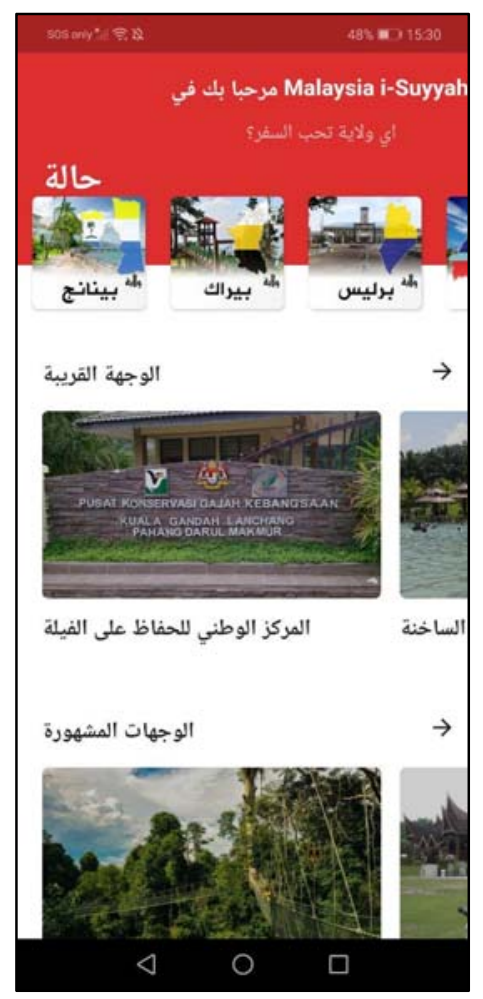

Figure 1: Main Menu

\section{List of States}

The i-Suyyah features tourism attractions in all 14 states in Malaysia. The information and descriptions for every destination are written in Arabic. In addition, the mobile application is linked with Google maps to make it easier for Arab tourists to locate and visit the tourism hotspots. Furthermore, the app provides recommendations for suitable accommodation in each state based on the users' preferences. 


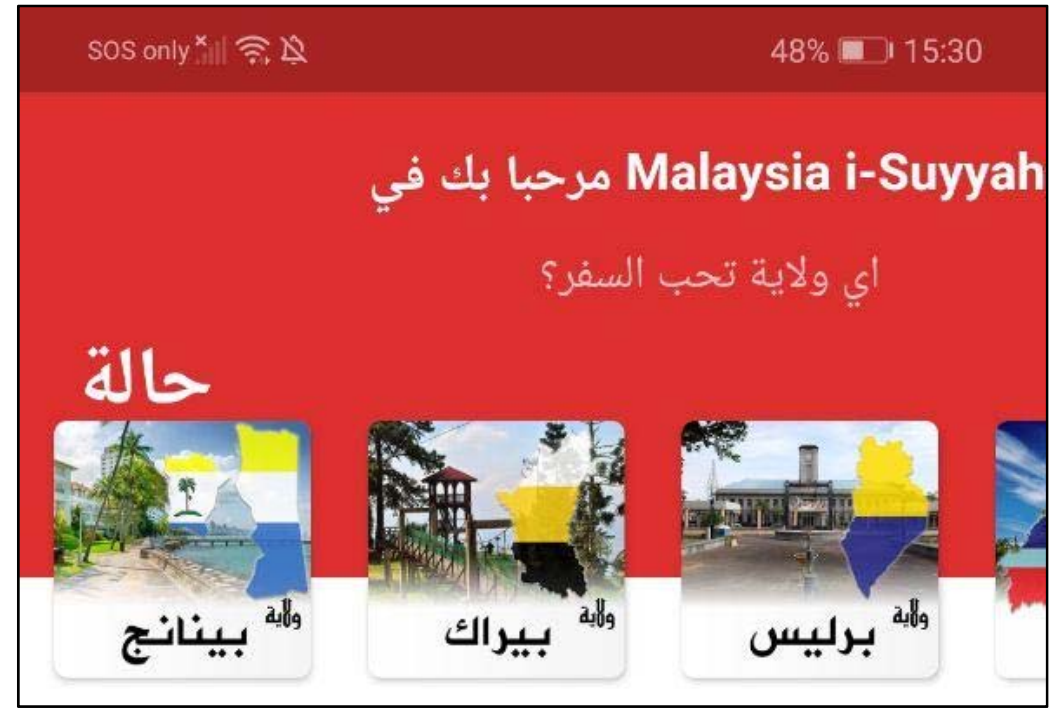

Figure 2: List of States 1

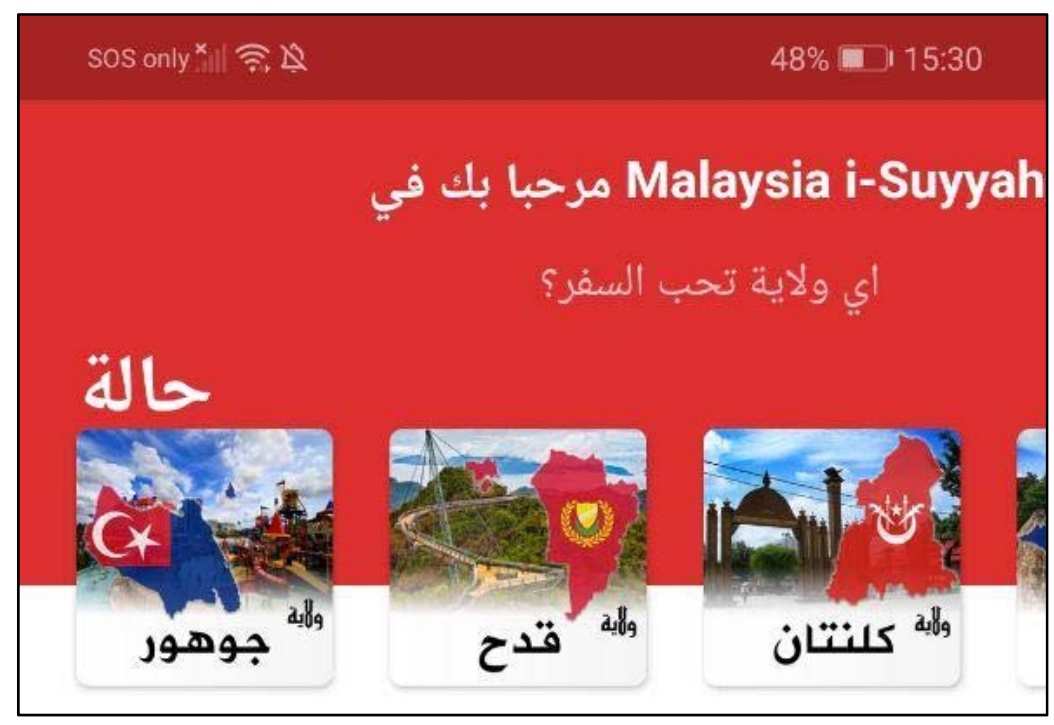

Figure 3: List of States 2

\section{METHODOLOGY}

The main approach used in this study is the Fuzzy Delphi technique. Murray, Pipino, and Gigch developed the Fuzzy Delphi system in 1985. This approach is prompted by a tweaked Delphi technique that incorporates Fuzzy Set Theory into the Delphi Method. The Fuzzy Delphi process has several procedures that must be completed for expert certification. In addition, the Fuzzy Delphi method by applying Binary Terms rating ranges from 0 to 1 , making this method faster and reducing the laps from Delphi's method. The Fuzzy Delphi approach will help the researchers save time and 
money on each questionnaire. This approach allows experts to completely articulate their views, guarantee perfection, and have explicit opinions while minimising the number of rounds of surveys. The Fuzzy Delphi approach should not misrepresent the expert's initial viewpoint and depicts their actual reaction.

Therefore, the Fuzzy Delphi technique was used to obtain experts' consensus (Mohd Ridhuan et al., 2017) on the usability of the i-Suyyah app and specifically, to determine the usability of i-Suyyah application, a seven-point system usability questionnaire was administered as the study instrument. The questionnaire determines the usability of the i-Suyyah application based on their agreement with the statement, and the Fuzzy scale will be aggregated and ranked from highest to lowest.

\section{1) INSTRUMENT}

The questionnaire used in this study was adapted from Lewis (1992) questionnaire on system usability. The items in the questionnaire focus on system usefulness, information quality and interface quality. The questionnaire sets were distributed to 12 experts, and they were required to evaluate the app's usability based on the agreement of the statement in each item.

\section{2) EXPERTS RESPONDENTS}

Ocampo et al. (2018) asserted that Delphi studies do not require a large number of experts. This is because there is no significant link between the number of experts and the quality of decisions generated by the discussion group. Thus, this study only selected experts with a strong background or experience in the related field, including Teaching Arabic as a second language, tourism and instructional technology. It is believed that these experts are able to use their professional judgement to justify their opinion and reach a consensus about the usability of the app. Saaty \& Ozdemir (2015) argued that choosing less experienced and knowledgeable 'experts' may compromise the results' accuracy. In line with this argument, this study selected 12 experts based on the recommendations by Adler and Ziglio (1996). In this regard, the appropriate number of experts is between 10 to 15 people if there is a high homogeneity among the selected experts. Hence, the experts for the evaluation were chosen based on the following criteria: 
1. Possess at least a postgraduate qualification (Master's degree) in the Arabic language, educational technology, language for tourism or other related areas.

2. Have at least five years of experience as an academic or professional in the related field.

3. Able to commit to the study until the study is completed.

4. Has no personal agenda and do not show any personal biases.

The table below provides the details of the experts chosen for the expert evaluation of the app.

\begin{tabular}{|c|c|c|c|}
\hline Name & Qualification & Expertise & $\begin{array}{l}\text { Experience } \\
\text { (Years) }\end{array}$ \\
\hline E1 & PhD & $\begin{array}{l}\text { 1. Computer Assisted Language Learning } \\
\text { 2. Teaching Arabic as a Second Language }\end{array}$ & 12 \\
\hline E2 & Master & $\begin{array}{l}\text { 1. e-Learning } \\
\text { 2. m-Learning }\end{array}$ & 9 \\
\hline E3 & PhD & 1. Teaching Arabic for Tourism Purpose & 18 \\
\hline E4 & $\mathrm{PhD}$ & $\begin{array}{l}\text { 1. Arabic Language } \\
\text { 2. Education }\end{array}$ & 18 \\
\hline E5 & PhD & $\begin{array}{l}\text { 1. Arabic Language } \\
\text { 2. Education }\end{array}$ & 18 \\
\hline E6 & PhD & $\begin{array}{l}\text { 1. Arabic Language and Literature } \\
\text { 2. Criticism }\end{array}$ & 23 \\
\hline E7 & PhD & $\begin{array}{l}\text { 1. Arabic Language } \\
\text { 2. Translation } \\
\text { 3. Lexicography } \\
\text { 4. Teaching Arabic as a Second Language }\end{array}$ & 23 \\
\hline E8 & PhD & $\begin{array}{l}\text { 1. Arabic Language } \\
\text { 2. Instructional Technology }\end{array}$ & 21 \\
\hline E9 & $\mathrm{PhD}$ & $\begin{array}{l}\text { 1. Instructional Technology } \\
\text { 2. Teaching Arabic as a Foreign Language } \\
\text { 3. Teaching Arabic as a Second Language }\end{array}$ & 25 \\
\hline E10 & PhD & $\begin{array}{l}\text { 1. Arabic Language } \\
\text { 2. Arabic Lexicography } \\
\text { 3. Arabic Discourse Analysis } \\
\text { 4. Teaching Arabic As Second Language }\end{array}$ & 16 \\
\hline E11 & PhD & $\begin{array}{l}\text { 1. Arabic Language Education } \\
\text { 2. e-Learning }\end{array}$ & 10 \\
\hline E12 & PhD & 1. Instructional Technology & 21 \\
\hline
\end{tabular}

Table 1: List of experts 


\section{3) DATA ANALYSIS}

Researchers employing the Fuzzy Delphi technique need to follow several steps. The steps in the Fuzzy Delphi technique are described below (Kardaras et al., 2013; Mohd Ridhuan et al., 2017).

\section{Step1: Determining the Experts}

As mentioned, this study chosen 12 experts based on the criteria mentioned above. These experts were required to provide their professional evaluation on the app to reach a consensus on whether the i-Suyyah app has high usability and suitable for Arab tourists in Malaysia. First, the researcher identified prospective experts through personal communication, involvement in research/conferences and recommendations from other colleagues. The researcher then approached prospective experts via face to face interactions, phone calls or email to invite them to be part of the research. After getting consent from the experts, the sets of questionnaires were emailed to each expert who agreed to participate in this study.

Step 2: Selecting a Linguistic Scale

A Fuzzy scale translates linguistic variables into Fuzzy numbers. The linguistic scale for the Fuzzy scale must contain odd numbers. Thus, this study uses a sevenpoint scale, as shown below.

\begin{tabular}{|l|c|c|}
\hline \multicolumn{1}{|c}{ Linguistic Variable (7 points) } & Likert Scale & Fuzzy Scale \\
\hline Strongly agree & 7 & $(0.90,1.00,1.00)$ \\
\hline Agree & 6 & $(0.70,0.90,1.00)$ \\
\hline More or less agree & 5 & $(0.50,0.70,0.90)$ \\
\hline Neutral & 4 & $(0.30,0.50,0.70)$ \\
\hline More or less disagree & 3 & $(0.10,0.30,0.50)$ \\
\hline Disagree & 2 & $(0.00,0.10,0.30)$ \\
\hline Strongly disagree & 1 & $(0.00,0.00,0.10)$ \\
\hline
\end{tabular}

Table 1: 7-points Fuzzy Scale

Step 3: Determining the Average Value

This process involved determining the average value of the Fuzzy scale for each item $(\mathrm{n} 1, \mathrm{n} 2, \mathrm{n} 3)$. 
Step 4: Determining the threshold value (d) and obtaining 75\% expert consensus

The threshold value determines the level of agreement or consensus amongst the expert respondents for all items in the instrument. The threshold values (d) higher than $0.2(d \geq 0.2)$ indicate that the experts do not reach any consensus among themselves (Mohd Ridhuan et al., 2017; Cheng \& Lin, 2002). As shown in Chen (2000), the threshold value can be obtained through,

$$
d(\tilde{m}, \tilde{n})=\sqrt{\frac{1}{3}}\left[\left(m_{1}-n_{1}\right)^{1}+\left(m_{2}-n_{2}\right)^{2}+\left(m_{3}-n_{3}\right)^{2}\right]
$$

The criteria used to assess the expert consensus are also based on the degree of consensus for each item $\leq 0.2$, which should exceed $75 \%$. If the degree of consensus less than $75 \%$, there is a need to conduct a second round of the Fuzzy Delphi Technique or discarding the item (Mohd Ridhuan et al., 2017). The degree of consensus can be obtained using;

$$
\frac{\sum d-\sum d}{\sum d} \times 100
$$

$\sum \mathrm{d} \quad$ total number of values of the expert's answer threshold.

$\sum \mathrm{d}_{1} \quad$ total number of ambiguous values that exceed 0.2 .

Step 5: Obtaining the Fuzzy Evaluation

All Fuzzy numbers are added to determine the Fuzzy aggregate evaluation.

Step 6: Defuzzification (determining the score)

The Defuzzification process will help obtain the ranking for each variable. The formula for the process is shown below.

$$
\operatorname{nmax}=\frac{1}{3}(n 1+n 2+n 3)
$$

Summary of the Fuzzy Delphi steps:

The table below summarises the steps in the Fuzzy Delphi technique. 


\begin{tabular}{|l|l|}
\hline \multicolumn{2}{|c|}{ Steps in Fuzzy Delphi Technique } \\
\begin{tabular}{|l} 
Step 1: Determining the number of \\
experts
\end{tabular} & $\begin{array}{l}\text { Twelve experts in their respective areas } \\
\text { of expertise were identified and } \\
\text { approached. They were required to } \\
\text { determine the validity and reliability of } \\
\text { the data. }\end{array}$ \\
\hline Step 2: Selecting a linguistic scale & $\begin{array}{l}\text { A 7-point scale was chosen to be used } \\
\text { as the Fuzzy scale. }\end{array}$ \\
\hline Step 3: Getting the average value & $\begin{array}{l}\text { This step involved obtaining the Fuzzy } \\
\text { value by adding all values from the } \\
\text { experts (d). d indicates the distance } \\
\text { between the two Fuzzy numbers, which } \\
\text { measure the deviation of the Fuzzy } \\
\text { average value from each expert }\end{array}$ \\
\hline Step 4: Determining the value of d & $\begin{array}{l}\text { The threshold value }(d) \text { was obtained. } \\
\text { (d) describes the degree of expert } \\
\text { consensus. It is based on the degree of } \\
\text { expert consensus } d \leq 0.2 \text {, which should } \\
\text { exceed 75\% for each item category. }\end{array}$ \\
\hline Step 5: Fuzzy evaluation process & $\begin{array}{l}\text { This process involved obtaining the } \\
\text { fuzzy triangular numbers for the } \\
\text { defuzzification process }\end{array}$ \\
\hline Step 6: Defuzzification process & $\begin{array}{l}\text { The Defuzzification values for the items } \\
\text { were ranked from high to low. }\end{array}$ \\
\hline
\end{tabular}

Table 3: Summary of Fuzzy Delphi Technique Steps 


\section{FINDINGS}

Twelve experts evaluated the usability of the i-Suyyah mobile app based on the usability questionnaire. The questionnaire consists of 17 questions. After the questionnaire was successfully returned and validated by experts, the group consensus was estimated. The difference between the two fuzzy numbers was calculated by measuring the deviation between average fuzzy evaluation data and the expert's evaluation data. Their responses were aggregated to obtain the expert's consensus on the usability of the app. As this study used the Fuzzy Delphi technique, the assessment criterion to assess expert consensus is based on their collective agreement. Thus, the level of expert consensus must exceed $75 \%$, and the threshold value (d) must be at 0.2 or lower. The table below summarises the Fuzzy Delphi Technique results of experts' consensus on system usability of the i-Suyyah mobile app.

\begin{tabular}{|c|c|c|c|c|c|c|c|c|c|c|}
\hline \multirow[t]{2}{*}{ No } & \multirow[t]{2}{*}{ Item } & \multicolumn{2}{|c|}{$\begin{array}{c}\text { Triangular Fuzzy } \\
\text { Numbers }\end{array}$} & \multicolumn{4}{|c|}{ Fuzzy Evaluation } & \multirow{2}{*}{$\begin{array}{c}\text { Expert } \\
\text { Agree- } \\
\text { ment }\end{array}$} & \multirow{2}{*}{$\begin{array}{c}\text { Item } \\
\text { Accep- } \\
\text { tance }\end{array}$} & \multirow[t]{2}{*}{$\begin{array}{l}\text { Rank- } \\
\text { ing }\end{array}$} \\
\hline & & $\begin{array}{c}d \\
\text { value }\end{array}$ & $\begin{array}{l}\text { Consen- } \\
\text { sus } \\
\text { value }\end{array}$ & m1 & $\mathrm{m} 2$ & m3 & $\begin{array}{l}\text { Skor } \\
\text { Fuzzy } \\
\text { (A) }\end{array}$ & & & \\
\hline 1 & $\begin{array}{l}\text { I am satisfied } \\
\text { with how easy it } \\
\text { is to use this i- } \\
\text { Suyyah. }\end{array}$ & 0.098 & $91.70 \%$ & 0.800 & 0.942 & 0.992 & 0.911 & Accept & 0.911 & 3 \\
\hline 2 & $\begin{array}{l}\text { It was simple to } \\
\text { use this i- } \\
\text { Suyyah. }\end{array}$ & 0.057 & $100 \%$ & 0.850 & 0.975 & 1.000 & 0.942 & Accept & 0.911 & 3 \\
\hline 3 & $\begin{array}{l}\text { I was able to } \\
\text { complete the } \\
\text { tasks (target } \\
\text { location) quickly } \\
\text { using this i- } \\
\text { Suyyah. }\end{array}$ & 0.068 & $100 \%$ & 0.767 & 0.933 & 1.000 & 0.900 & Accept & 0.900 & 7 \\
\hline 4 & $\begin{array}{l}\text { I felt comfortable } \\
\text { using this i- } \\
\text { Suyyah. }\end{array}$ & 0.141 & $100 \%$ & 0.750 & 0.900 & 0.975 & 0.875 & Accept & 0.875 & 8 \\
\hline 5 & $\begin{array}{l}\text { It was easy to } \\
\text { learn to use this } \\
\text { i-Suyyah. }\end{array}$ & 0.098 & $91.67 \%$ & 0.800 & 0.942 & 0.992 & 0.911 & Accept & 0.911 & 3 \\
\hline 6 & $\begin{array}{l}\text { I believe I could } \\
\text { become } \\
\text { productive } \\
\text { quickly using } \\
\text { this i-Suyyah. }\end{array}$ & 0.167 & $91.67 \%$ & 0.717 & 0.875 & 0.958 & 0.850 & Accept & 0.850 & 11 \\
\hline 7 & $\begin{array}{l}\text { The i-Suyyah } \\
\text { gave error } \\
\text { messages that } \\
\text { clearly told me } \\
\text { how to fix } \\
\text { problems. }\end{array}$ & 0.129 & $100 \%$ & 0.667 & 0.850 & 0.967 & 0.828 & Accept & 0.588 & 17 \\
\hline
\end{tabular}




\begin{tabular}{|c|c|c|c|c|c|c|c|c|c|c|}
\hline 8 & $\begin{array}{l}\text { Whenever I } \\
\text { made a mistake } \\
\text { using the i- } \\
\text { Suyyah, I could } \\
\text { recover easily } \\
\text { and quickly. }\end{array}$ & 0.129 & $91.67 \%$ & 0.700 & 0.875 & 0.967 & 0.847 & Accept & 0.769 & 15 \\
\hline 9 & $\begin{array}{l}\text { The information } \\
\text { provided with } \\
\text { this i-Suyyah } \\
\text { was clear. }\end{array}$ & 0.162 & $91.67 \%$ & 0.650 & 0.833 & 0.950 & 0.811 & Accept & 0.811 & 13 \\
\hline 10 & $\begin{array}{l}\text { It was easy to } \\
\text { find the } \\
\text { information I } \\
\text { needed. }\end{array}$ & 0.122 & $83.33 \%$ & 0.800 & 0.933 & 0.983 & 0.906 & Accept & 0.906 & 6 \\
\hline 11 & $\begin{array}{l}\text { The information } \\
\text { was useful in } \\
\text { helping me } \\
\text { complete the } \\
\text { tasks. }\end{array}$ & 0.187 & $91.67 \%$ & 0.700 & 0.858 & 0.950 & 0.836 & Accept & 0.836 & 12 \\
\hline 12 & $\begin{array}{l}\text { The organisation } \\
\text { of information on } \\
\text { the screens was } \\
\text { clear. }\end{array}$ & 0.057 & $100 \%$ & 0.850 & 0.975 & 1.000 & 0.942 & Accept & 0.942 & 1 \\
\hline 13 & $\begin{array}{l}\text { The interface of } \\
\text { this i-Suyyah } \\
\text { was pleasant. }\end{array}$ & 0.136 & $91.67 \%$ & 0.717 & 0.883 & 0.967 & 0.856 & Accept & 0.856 & 10 \\
\hline 14 & $\begin{array}{l}\text { I liked using the } \\
\text { interface of this } \\
\text { i-Suyyah. }\end{array}$ & 0.076 & $100 \%$ & 0.800 & 0.950 & 1.000 & 0.917 & Accept & 0.917 & 2 \\
\hline 15 & $\begin{array}{l}\text { This i-Suyyah } \\
\text { has all the } \\
\text { functions I } \\
\text { expect it to } \\
\text { have. }\end{array}$ & 0.195 & $83.33 \%$ & 0.633 & 0.817 & 0.933 & 0.794 & Accept & 0.794 & 14 \\
\hline 16 & $\begin{array}{l}\text { This i-Suyyah } \\
\text { has all the } \\
\text { capabilities I } \\
\text { expect it to } \\
\text { have. }\end{array}$ & 0.119 & $91.67 \%$ & 0.750 & 0.908 & 0.975 & 0.878 & Accept & 0.758 & 16 \\
\hline 17 & $\begin{array}{l}\text { I am satisfied } \\
\text { with this i- } \\
\text { Suyyah. }\end{array}$ & 0.134 & $100 \%$ & 0.733 & 0.892 & 0.975 & 0.867 & Accept & 0.867 & 9 \\
\hline
\end{tabular}

Table 4 Expert Consensus Through Fuzzy Delphi Technique. 
The table above shows the threshold value for each item and the percentage of experts' consensus on the usability of the i-Suyyah application. The threshold value of each item ranges from 0.057 to 0.195 . Furthermore, the percentage of consensus is between $83.33 \%$ to $100 \%$, which is above $75 \%$. As items obtained the threshold values $(d)$ of less than 0.2 and consensus percentage exceeding $75 \%$, it could be deduced that the experts have reached a consensus on the usability of the i-Suyyah mobile app.

\section{DISCUSSION}

This study evaluates the usability of i-Suyyah, a mobile tourism application for Arab tourists in Malaysia, based on experts' consensus. In general, the experts reached the consensus that the app is user friendly and can be used to fulfil the travelling needs of Arab tourists. The item with the highest defuzzification value is 'The organisation of information on the screens was clear' at 0.942 . This indicates the tourism information presented in the app is highly organised. The information is organised clearly gives positive user's experience, which actually allows them to feel unique and relevant to what/ where they are looking for. The visible and invisible interaction between the application and the users is the most important factor to sustain the engagement. $A$ good user experience is crucial for tourists and affects user acceptance and satisfaction.

The expert evaluation also indicates that the app has user-friendly features that could improve the perceived ease of use for the i-Suyyah mobile app. In this light, the 'enjoyment in using the interface's application' obtained the second-highest defuzzification value with 0.917 . This shows that most experts like the interface of the i-Suyyah app. The study also found that the i-Suyyah app has an interactive, unique and user-friendly interface that could help Arab tourists to use and navigate the application. There are three items with the third-highest defuzzification value of 0.911 , which are perceived ease of use, the simplicity of the application, and easy to learn how to use the application. These items are followed by 'the easiness to find the information needed' with a defuzzification value of 0.906 . The majority of the experts agreed that it is easy to find information using the i-Suyyah mobile app. The information in the application is organised according to each state. The app also lists the attraction based on popularity. The application also enhanced visible interaction 
and invisible interaction to allow users to have a good experience when searching for the information they need.

The next item is 'the ability to complete the task quickly using the i-Suyyah' with the defuzzification value of 0.900 . The experts have reached the consensus that the iSuyyah app helps them to discover targeted places, and the map could help them to locate and reach the destination that they intend to visit. This item is followed by 'comfortable using the i-Suyyah' (0.875) and most of the experts agreed that they are comfortable using the application. This is because the application provides all information they need, has many user-friendly features and can be used by users from all age group without any difficulty. The good experience in travelling along with the iSuyyah application leads to improve the degree of tourist satisfaction and sustain the engagement of user application. The next item is 'satisfy with the i-Suyyah' (0.867) app. This indicates that experts have reached the agreement that they are satisfied with this mobile application. In this regard, Arab tourists might use this application as the main guide when they are travelling in Malaysia as it provides them with precise information in their native language.

Item, 'the interface of i-Suyyah, is pleasant' obtained the defuzzification value of 0.856' followed by 'the user could become productive quickly using the i-Suyyah application' (0.850). The experts agreed that the use of this app helps users to become more productive as the application provides information on popular tourist attractions and can the Arab tourist to reach the tourist attraction they want to visit. Besides, this application also provides them with a recommendation on the best accommodation within the area. In other words, Arab tourists can use this application to ease their vacation planning and to move around while vacationing in Malaysia. The next item is 'information is useful in helping the user complete the task' with the defuzzification value of 0.836 , followed by 'the information provided by the i-Suyyah app is clear' (0.811). As mentioned before, this application assists users on several aspects such as describing tourist attractions, recommendations of the best places to stay, and link to Google maps for direction to the tourist attractions. These elements in i-Suyyah allow the tourists to plan their trip more flexibly while making more context-relevant decision based on their immediate environment and eventually provide more choices among tourist. 
'The function users expect to have' recorded defuzzification value of 0.794 . Meanwhile, 'the capabilities users expected to have' showed the defuzzification value of 0.758 . The results show that the application provides all the functions needed by the tourists. It also covers all the capabilities as a mobile application for tourism. Meanwhile, the 'error message that told the users how to fix' ranked the last. In this regard, the expert found that while there are pop-up messages that will notify the users of any bug or error in the system application, they think this function is less user friendly to the users.

\section{CONCLUSION}

This study examined the usability of i-Suyyah tourism mobile application for Arab tourists in Malaysia. This application is successfully uploaded to Google Play Store, and 12 experts measured its usability through the Fuzzy Delphi method. The study found that this mobile application for tourism has high usability for Arab tourists in Malaysia as the expert consensus scores were between $83 \%$ to $100 \%$. Hence this study provides empirical evidence on the internal usability of travel mobile application through expert consensus. The majority of the experts agreed that the i-Suyyah has high performance on its usability and can be employed among Arab tourist. Therefore, this study would like to recommend future studies to conduct a qualitative study that specifically uses semi-structured interviews to gauge users' opinions on the use of the i-Suyyah app among Arab tourists' in Malaysia and analyse through Fuzzy Delphi methods.

\section{Acknowledgement}

The authors would like to acknowledge the Research Management Centre Universiti Malaysia Kelantan for funding through Skim Geran Jangka Pendek Impak (SGJP-IMPAK) - (R/SGJ P/ A0400/01659A/002/2019/00680).

\section{References}

Adler, M.; Ziglio, E. Gazing Into The Oracle: The Delphi Method and Its Application to Social Policy and Public Health. London: Jessica Kingsley Publisher, 1996.

Ahas, R.; Aasa, A.; Roose, A.; Mark, U.; Slim, S. Evaluating Passive Mobile Positioning Data for Tourism Surveys: An Estonian Case Study. Tourism Management, Vol. 29, No. 3, 2008, pp. 469-486. 
Alganam, A. An Increase in Switzerland's Tourist from the Gulf by $13 \%$. Riyadh Newspaper. 2011, April 22.

Alsheikh, E. Survey: Arabs Travel for Shopping First. Middle East: Arab International Newspaper, 1. 2006, March 26.

Ariffin, A.; Hasim, M. Marketing Malaysia to the Middle East Tourists: Towards a Preferred Inter-regional Destination. International Journal of West Asian Studies, Vol. 1, 2009, pp. 39-53.

Baltrunas, L.; Ludwig, B.; Peer, S.; Ricci, F. Context Relevance Assessment and Exploitation in Mobile Recommender System. Personal and Ubiquitous Computing, Vol. 16, No. 5, 2012, pp. 507-526.

Batet, M.; Moreno, A.; Sanchez, D.; Isern, D.; Valls, A. Turist: Agent-based Personalised Recommendation of Tourist Activities. Expert Systems with Applications, Vol. 39, No. 8, 2012, pp. 7319-7329.

Beritelli, P.; Schuppisser, M. Challenges in Mobile Business Solutions for Tourist Destinations - The Trial Case of St. Moritz. Journal of Quality Assurance in Hospitality \& Tourism, Vol. 6, No. 3, 2006, pp. 147-162.

Bernama. Kementerian Kewangan Jangka 2 juta Pelancong Penjagaan Kesihatan Menjelang 2020. 2018, September 3.

Bernama. Malaysia Seeing Sharp Increase in Arab Tourist Arrivals. 2019, May 05.

Buhalis, D.; Law, R. Progress in Information Technology and Tourism Management: 20 Years on and 10 years After The Internet - The State of eTourism Research. Tourism Management, Vol. 29, No. 4, 2008, pp. 609-623.

Burgess, S.; Sellitto, C.; Karanasios, S. A Model of ICDT Interet Flows on Mobile Devices for the Travel and Tourism Consumer. Tourism Analysis, Vol. 17, No.6, 2012, pp. 705-719.

Chen, C.T. Extensions of the TOPSIS for Group Decision-Making Under Fuzzy Environment. Fuzzy Sets and Systems, Vol. 114, 2000, pp. 1-9. 
Cheng, C.H.; Lin, Y. Evaluating the best Main Battle Tank using Fuzzy Decision Theory with Linguistic Criteria Evaluation. European Journal of Operational Research, Vol. 142, No. 1, 2002, pp. 174-186.

D'Ambra, J.; Mistilis, N. Assessing the e-Capability of Visitor Information Centers. Journal of Travel Research, Vol. 49, No. 2, 2010, pp. 216-215.

Egger, R. The Impact of Near Field Communication on Tourism. Journal of Hospitality and Tourism Technology, Vol. 4, No.2, 2013, pp. 119-133.

Firyaan, K. Favourite Countries of the Middle East for Saudi Tourists, Followed by Asia Europe. Riyadh Newspaper, 1. 2011, November 9.

Gavalas, D.; Kenteris, M. A Web-Based Pervasive Recommendation System for Mobile Tourist Guides. Personal and Ubiquitous Computing, Vol. 15, No. 7, 2011, pp. 759-770.

Gil, A.; Fraile, F.; Ramos, M.; Fez, I.; Guerri, J.C. Personalized Multimedia Touristic Services for Hybrid Broadcast/Broadband Mobile Receivers. IEEE Transactions on Consumer Electronics, Vol. 56, No. 1, 2010, pp. 211-219.

Hannam, K.; Butler, G.; Paris, C.M. Development and Key Issues in Tourism Mobilities. Annals of Tourism Research, Vol. 44, 2014, pp. 171-185.

Hultkrantz, L. Will There be a Unified Wireless Market Place for Tourism?. Current Issues in Tourism, Vol. 5, No. 2, 2002, pp. 149-161.

Kardaras, D.K.; Karakostas, B.; Mamakou, X.J. Content Presentation Personalisation and Media Adaptation in Tourism Web Sites Using Fuzzy Delphi Method and Fuzzy Cognitive Maps. Expert Systems with Applications, Vol. 40, No. 6, 2013, pp. 23312342.

Kennedy-Eden, H.; Gretzel, U. A Taxonomy of Mobile Applications in Tourism. EReview of Tourism Research, Vol. 10, No. 2, 2012, pp. 47-50.

Kenteris, M.; Gavalas, D.; Economou, D. Mytilene E-Guide: A Multiplatform Mobile Application Tourist Guide Exemplar. Multimedia Tools and Applications, Vo. 54, No. 2, 2011, pp. 241-262. 
Latorre-Martines, M.P.; Iniguez-Berrozpe, T.; Plumed-Lasarte, M. Image-Facused Social Media for a Market Analysis of Tourism Consumption. International Journal of Technology Management, Vol. 64, No. 1, 2014, pp. 17-30.

Lewis, J.R. Psychometric Evaluation of The Post-Study System Usability Questionnaire: The PSSUQ. Proceeding of the Human Factors Society 36th Annual Meeting, 1992, pp. 1259-1263.

Liang, S.; Sun, W.J. Research on Microblogging Original Posts Release Behavior Based on Panel data of Mobile Application. In H. Lua (Ed). International Conference on Management Science \& Engineering, 2014 , pp. 43-49.

Liu, J.N.; Zhang, E.Y. An Investigation of Factors Affecting Customers Selection of Online Hotel Booking Channels. International Journal of Hospitality Management, Vol. 39, No. May, 2014, pp. 71-83.

Marentakis, C.; Emiris, D. Location Aware Auctions for Tourism Services. Journal of Hospitality and Tourism Technology, Vol. 1, No. 2, 2010, pp.121-143.

Martin, D.; De Ipina, D.L.; Lamsfus, C.; Alzua, A. Involving Tourism Domain Experts in The Development of Context-Aware Mobile Services. E-Review of Tourism Research, Vol. 10, No. 3, 2012, pp. 1-5.

Michael, I.; Armstrong, A.; Badran, B.; King, B. Dubai Outbound Tourism: An Exploratory Study of Emiratis and Expatriates. Journal of Vacation Marketing, Vol. 17, No. 1, 2011, pp. 83-91.

Mick, H. Arab Tourists Flocking to Gold Coast. ABS news. 2007. Retrieved from https://www.abc.net.au/news/2007-09-29/arab-tourists-flocking-to-gold-coast/684458 [accessed 17 February 2021].

Mistilis, N.; Buhalis, D.; Gretzel, U. Future eDestination Marketing Perspective of an Australian Tourism Stakeholder Network. Journal of Travel Research, Vol. 53, No. 6, 2014, pp. 778-790.

Mohd Ridhuan, M.J.; Saedah, S.; Zaharah, H.; Nurulrabihah, M.N.; Ahmad Ariffin, S. Pengenalan Asas Kaedah Fuzzy Delphi dalam Penyelidikan Reka Bentuk dan Pembangunan. Selangor: Minda Intelek Agency, 2017. 
Noguera, J.M.; Barranco, M.J.; Segura, R.J.; Martinez, L. A Mobile 3D-GIS Hybrid Recommender System for Tourism. Information Sciences, Vol. 215, 2012, pp. 37-52.

Ocampo, L.; Ebisa, J.A.; Ombe, J.; Geen Escoto, M. Sustainable Ecotourism Indicators with Fuzzy Delphi Method: A Philippine Perspective. Ecological Indiscators, Vol. 93, 2018, pp. 874-888.

Perdana, M. Location-Based Services and Tourism: Possible Implications for Destination. Current Issues in Tourism, Vol. 17, No. 9, 2014, pp. 753-762.

Pesonen, J.; Horster, E. Near Field Communication Technology in Tourism. Tourism Management Perspective, Vol. 4, 2012, pp. 11-18.

Reilly, D.; Rodgers, M.; Argue, R.; Nunes, M.; Inkpen, K. Marked-up Maps: Combining Paper Maps and Electronic Information Resources. Personal and Ubiquitous Computing, Vol. 10, No. 4, 2006, pp. 215-226.

Saaty, T.L.; Ozdemir, M.S. How Manu Judges Should There Be in a Group?. Annals of Data Science, Vol. 1, 2015, pp. 359-368.

Said, E.G.; Omar, E.B.; Robert, R. Data Prefetching Algorithm in Mobile Environments. European Journal of Scientific Research, Vol. 28, No. 3, 2009, pp. 478-491.

Stienmetz, J.L.; Levy, S.E.; Boo, S. Factors Influencing The Usability of Mobile Destination Management Organization Websites. Journal of Travel Research, Vol. 52, No. 4, 2013, pp. 453-464.

Tatsiopoulos, C.; Boutsinas, B. Automatic Knowledge Exchanging Between Tourists Via Mobile Devices. Journal of Hospitality and Tourism Technology, Vol. 1, No. 2, 2010, pp. 163-173.

Thakran, K.; Verma, R. The Emergence of Hybrid Online Distribution Channels in Travel, Tourism and Hospitality. Cornell Hospitaity Quarterly, Vol. 54, No. 3, 2013, pp. 240-247.

Tourism Malaysia. 2019. Retrieved from https://www.tourism.gov.my/statistics [accessed 17 February 2021]. 
Wang, H.Y.; Wang S.H. Predicting Mobile Hotel Reservation Adoption: Insight from a Perceived Value Standpoint. International Journal of Hospitality Management, Vol. 29, No. 4, 2010, pp. 598-608.

Yim, J. Design of The Location Based Service System for Local Area Tourism. International Information Institute (Tokyo), Vol. 18, No. 5B, 2015, pp. 2137-2142.

Yovcheva, Z.; Buhalis, D.; Gatzidis, C. Smartphone Augmented Reality Applications for Tourism. e-Review Tourism Research (eRTR), Vol. 10, No. 2, 2012, pp. 63-66.

Zhong, L.; Leung, D., Law, R.; Wu, B. eTourism in China: A Review of The ChineseLanguage Literature. Asia Pacific of Tourism Research, Vol. 18, No. 5, 2013, pp. 464482.

Article info: Received 02/12/2020. Accepted 04/05/2021. Refereed anonymously. 